\title{
Opinion and Constraints Analysis in Barren Land Development under Tribal Area Development Programme on Tribals of Udaipur District
}

\author{
Sonali Sharma*
}

SMS (Home Science), KVK-Barmer (Raj.), India

*Corresponding author:

\section{A B S T R A C T}

\section{Keywords}

Tribal area development programme, Jatropha plantation

Article Info

Accepted:

07 March 2019

Available Online:

10 April 2019

\begin{abstract}
Tribal development in India is a big challenge as the gap between the ideal and reality is not only woeful but widening with the passage of time. The study was conducted in Udaipur district of Rajasthan as for the development of tribals a separate department i.e. Tribal Area Development Department is in function. These Barren Lands Development through Jatropha plantation were being implemented in seven tribal blocks of Udaipur district at the time of planning the study namely Jhadol, Sarada, Lasadiya, Kotra, Kherwara, Gogunda and Salumber. Over all it can be concluded Barren Land Development through Jatropha plantation service, 96.66 per cent beneficiaries had favourable opinion with MWS 2.21 and only 3.33 beneficiaries had showed favourable opinion and 93.33 per cent beneficiaries experiencing constraints to great extent also depicts in MPS 74.00.
\end{abstract}

\section{Introduction}

The tribals form an integral part of India's social fabric and have second largest concentration of tribal population in the world after that of the African continent. Tribals are most primitive people living in isolation and constitute 8.61 per cent of the total population of the country, numbering 104,281,034 millions, out of which $93,819,162$ residing in rural area and 10,461,872 living in urban area.

The country's 15 per cent of the total geographical area are covered by tribal population. They reside mainly in forests, hills and undulating inaccessible terrain in plateau areas, rich in natural resources (India census 2011). Tribal Development in India is a big challenge as the gap between the ideal and reality is not only woeful but widening with the passage of time. The Tribal situations in India present a varied and comparative picture and possess particular problems of economic development, as each tribe has different socio-economic situation, environment, historical experience and the extent of political articulation. On account of these factors, ethnically as well as culturally the tribes remain at different stages of sociopsychological orientation and political economic development. 
Rajasthan is the largest state in the country having geographical area of $3,42,339 \mathrm{sq} . \mathrm{km}$ or 10.41 per cent of the total geographical area of the country. The population of Rajasthan according to Census 2011 stands at about 68 million, making it the 8th most populated state in India, the population of Scheduled Tribe is 9,238,534, further in rural areas 8,693,123 tribal and 545,411 tribal in urban areas of the state, but the concentration of the ST population is greater in some parts of the state.

With the view to bring the tribal areas or people of the country in the mainstream of economic development and accelerating the pace of socio-economic development, the State Government has made significant efforts to uplift the tribal people and started various activities for their social and economic development.

A special programme, known as Tribal Area Developmental Programme (TADP) was taken up, on a pilot basis under a central sector plan scheme of the Ministry of Agriculture in 1964.

\section{Objectives of the study}

To study the opinion of beneficiaries towards Horticulture Development promoted under TADP.

To study the opinion of beneficiaries towards Jatropha plantation promoted under TADP.

To explore the constraints faced by the beneficiaries of the TADP.

\section{Opinion}

Opinion in the present study is conceptualized as the personal view of tribal beneficiaries positive or negative about agricultural services promoted under Tribal Area Development Programme.

\section{Constraints}

It refers to the obstacles in adoption of improved practices of agricultural services by the beneficiaries of TADP.

\section{Materials and Methods}

The study was conducted in Udaipur district of Rajasthan as for the development of tribals a separate department i.e. Tribal Area Development Department is in function. These Barren land Development were being implemented in seven tribal blocks of Udaipur district at the time of planning the study namely Jhadol, Sarada, Lasadiya, Kotra, Kherwara, Gogunda and Salumber.

\section{Selection and development of research tool}

In view of the study objectives and nature of respondents, interview technique was selected for data collection. This technique was considered most appropriate technique to collect in-depth information from tribals, as it help in face-to-face interaction along with clarification of doubts if any. The interview schedule was developed by the researcher after extensive review of literature, material collected from the concerned departments and organization and in consultation with the subject matter specialists from the discipline of Agronomy, Animal Husbandry, Horticulture and Extension Education from Maharana Pratap University of Agriculture and Technology, Udaipur.

\section{Scoring procedure}

The scoring of the schedule was finalized in consultation with the expert. The scoring in part of the interview schedule was as follows:

Opinion - It consists of positive and negative statements in each service therefore assessed on three point continuum as agree, undecided and disagree with the scores of 3,2 and 1 
respectively for positive statements and 1, 2 and 3 respectively for negative statements. Constraints tool - Constraints were assessed on three point continuum as Great extent, some extent and least extent with scores 3, 2 and 1 respectively.

\section{Measurement of opinion}

The respondent's opinion towards positive and negative statements in Horticulture Development was measured.

\section{Measurement of constraints}

There were varied number of constraints in each Agriculture service grouped under Personal, technical, economic and general constraints.

After collecting data it was necessary to analyze with the help of statistics to derive proper and adequate conclusion. Therefore, obtained data were coded, tabulated and analyzed with the help of statistical tools and techniques.

\section{Results and Discussion}

\section{Opinion of beneficiaries towards barren land development (Jatropha plantation)}

Opinion of the beneficiaries was studied towards Barren Land Development (Jatropha Plantion) promoted under TADP. The statement wise results are presented in Table 1. It is apparent from the data presented in Table 1 about opinion of beneficiaries towards Jatropha Plantation that majority of the beneficiaries (70 to $100 \%$ ) agreed that jatopha plantation increases income $(100 \%)$, requires minimum care $(100 \%)$, not-browsed by animals (100\%), easy to propagate $(100 \%)$, make productive use of waste land (90 \%) and a very useful crop (73.33\%). A good number of beneficiaries $(56.66 \%)$ also agree that Jatropha Plantation controls soil erosion with 26.66 per cent beneficiaries remained neutral and only 13.33 per cent beneficiaries disagree towards this aspect. Further, jatropha is not a source of fuel wood, it's time taking crop, lot of legal restriction to cultivate jatropha and inadequate processing unit followed by appropriate for lively hood security were also agreed by $83.33,80,76.66$, 70 and 43.33 per cent beneficiaries respectively. Reasons behind this opinion among beneficiaries may be that most of the beneficiaries consider this service fruitful as it utilizes their barren land and they can manage this crop with other crop simultaneously. Majority of beneficiaries i.e. 83.33 per cent disagreeing towards Jatropha Plantation as labour intensive work followed by cultivation is waste of time and energy (66.66 \%). Further 53.33 to 90 per cent of the beneficiaries were undecided as it helps in protecting environment, fencing by it affect crop production and oil extraction as an input intensive task. It was due to the reason that beneficiaries were unaware about advantages of jatropha its post harvest practices. These findings indicate that beneficiaries were agreeing with positive as well as negative statements means does not exist with Jatropha Plantation.

\section{Constraints faced by the beneficiaries of barren land development through Jatropha plantation programme}

A critical look of Table 2 reveals that the major constraints faced by the beneficiaries of Barren Land Development through Jatropha Plantation service were personal (78.88 MPS) economic (77.77 MPS) and technical (73.33 MPS) followed by general (65.77 MPS) constraints with rank I to IV respectively. Further, the table shows that the major personal constraints perceived by the beneficiaries of Barren Land Development through Jatropha Plantation were 
unawareness about medicinal value of jatropa (93.33 MPS), lack of knowledge about advantages of jatropa (86.66 MPS), lack of knowledge about scientific cultivation ( 84.33 MPS), lack of motivation, guidance and information (78.66 MPS) and inadequate land for nursery raising (70 MPS). Unawareness about bio-diesel use of jatropa (60 MPS) was the only personal constraint faced by the beneficiaries of the service to some extent.

Table.1 Distribution of beneficiaries by their opinion towards

Barren Land Development through Jatropha Plantation

\begin{tabular}{|c|c|c|c|c|}
\hline S.No & Statements & $\begin{array}{l}\text { Agree } \\
\mathbf{f}(\%)\end{array}$ & $\begin{array}{c}\text { Undecided } \\
\mathbf{f}(\%)\end{array}$ & $\begin{array}{c}\text { Disagree } \\
\mathbf{f}(\%)\end{array}$ \\
\hline 1. & Increases the income & $\begin{array}{c}30 \\
(100)\end{array}$ & 0 & 0 \\
\hline 2. & Time taking crop & $\begin{array}{c}24 \\
(80)\end{array}$ & $\begin{array}{c}6 \\
(20)\end{array}$ & 0 \\
\hline 3. & Can make productive use of waste land & $\begin{array}{c}27 \\
(90)\end{array}$ & $\begin{array}{c}3 \\
(10)\end{array}$ & 0 \\
\hline 4. & Helps in protecting environment & $\begin{array}{c}2 \\
(6.66)\end{array}$ & $\begin{array}{c}25 \\
(83.33)\end{array}$ & $\begin{array}{c}3 \\
(10)\end{array}$ \\
\hline 5. & Minimum care crop & $\begin{array}{c}30 \\
(100)\end{array}$ & 0 & 0 \\
\hline 6. & Labour intensive work & $\begin{array}{c}3 \\
(10)\end{array}$ & $\begin{array}{c}2 \\
(6.66)\end{array}$ & $\begin{array}{c}25 \\
(83.33)\end{array}$ \\
\hline 7. & Helps to check soil erosion and desertification & $\begin{array}{c}18 \\
(56.66)\end{array}$ & $\begin{array}{c}8 \\
(26.66)\end{array}$ & $\begin{array}{c}4 \\
(13.33)\end{array}$ \\
\hline 8. & Fencing by it affect the crop production & $\begin{array}{c}7 \\
(23.33)\end{array}$ & $\begin{array}{c}16 \\
(53.33)\end{array}$ & $\begin{array}{c}7 \\
(23.33)\end{array}$ \\
\hline 9. & Very useful crop & $\begin{array}{c}22 \\
(73.33)\end{array}$ & $\begin{array}{c}5 \\
(16.66)\end{array}$ & $\begin{array}{c}3 \\
(10)\end{array}$ \\
\hline 10. & Appropriate for lively hood security & $\begin{array}{c}13 \\
(43.33)\end{array}$ & $\begin{array}{c}11 \\
(36.66)\end{array}$ & $\begin{array}{c}6 \\
(20)\end{array}$ \\
\hline 11. & Lot of legal restriction to cultivate jatropha & $\begin{array}{c}23 \\
(76.66)\end{array}$ & $\begin{array}{c}7 \\
(23.33)\end{array}$ & 0 \\
\hline 12. & Cultivation is waste of time and energy & $\begin{array}{c}6 \\
(20)\end{array}$ & $\begin{array}{c}4 \\
(13.33)\end{array}$ & $\begin{array}{c}20 \\
(66.66)\end{array}$ \\
\hline 13. & Easily propagated & $\begin{array}{c}30 \\
(100)\end{array}$ & 0 & 0 \\
\hline 14. & Problem in marketing & $\begin{array}{c}17 \\
(56.66)\end{array}$ & $\begin{array}{c}4 \\
(13.33)\end{array}$ & $\begin{array}{c}9 \\
(30)\end{array}$ \\
\hline 15. & Not a source of fuel wood & $\begin{array}{c}25 \\
(83.33)\end{array}$ & $\begin{array}{c}5 \\
(16.66)\end{array}$ & 0 \\
\hline 16. & Oil extraction is an input intensive task & $\begin{array}{c}3 \\
(10)\end{array}$ & $\begin{array}{c}27 \\
(90)\end{array}$ & 0 \\
\hline 17. & Non-browsed by animals & $\begin{array}{c}30 \\
(100)\end{array}$ & 0 & 0 \\
\hline 18. & Inadequate processing unit & $\begin{array}{c}21 \\
(70)\end{array}$ & $\begin{array}{c}9 \\
(30)\end{array}$ & 0 \\
\hline
\end{tabular}


Table.2 Constraints faced by the beneficiaries of barren land development through Jatropha plantation

\begin{tabular}{|c|c|c|c|}
\hline \multicolumn{2}{|r|}{ 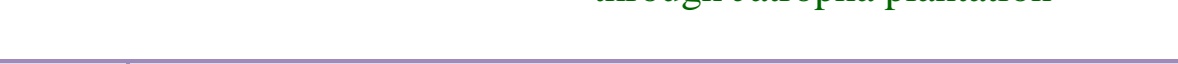 } & \multicolumn{2}{|c|}{$\mathrm{n}=30$} \\
\hline S.No & Constraints & MPS & Rank \\
\hline \multicolumn{4}{|c|}{ Development of Barren land through Jatropha } \\
\hline 1 & Personal & & \multirow{8}{*}{$\mathbf{I}$} \\
\hline i. & Unawareness about medicinal value of jatropa & 93.33 & \\
\hline ii. & Lack of knowledge about advantages of jatropa & 86.66 & \\
\hline iii. & Lack of knowledge about scientific cultivation & 84.33 & \\
\hline iv. & Lack of motivation, guidance and information & 78.66 & \\
\hline v. & Inadequate land for nursery raising & 70 & \\
\hline \multirow[t]{2}{*}{ vi } & Unawareness about bio-diesel use of jatropa & 60 & \\
\hline & Over all & 78.88 & \\
\hline 2 & \multicolumn{2}{|l|}{ Technical } & \multirow{7}{*}{ III } \\
\hline i. & Long maturity period & 95.33 & \\
\hline ii. & Non - availability of oil extraction unit in the area & 81 & \\
\hline iii. & Extremely degraded conditions of soil at the plantation site & 71 & \\
\hline iv. & Non availability of improved varieties & 67.66 & \\
\hline \multirow[t]{2}{*}{ v. } & Lack of training & 51 & \\
\hline & Over all & 73.33 & \\
\hline 2 & $\begin{array}{r}\text { Economic } \\
\end{array}$ & & \multirow{6}{*}{ II } \\
\hline i. & Less price of jatropa produce in the market & 97.66 & \\
\hline ii. & Lack of finance facilities & 86.66 & \\
\hline iii. & Lack of marketing facilities for sale of produce & 66.66 & \\
\hline \multirow[t]{2}{*}{ iv. } & Higher cost of inputs & 60 & \\
\hline & Over all & 77.77 & \\
\hline 4 & \multicolumn{2}{|l|}{ General } & \multirow{7}{*}{ IV } \\
\hline i. & High mortality in the first year of plantation & 76.66 & \\
\hline ii. & Insufficient labour during work season & 75.33 & \\
\hline iii. & Lack of irrigation facilities for raising seedlings & 67.66 & \\
\hline iv. & Absence of procurement policy of the government & 55.33 & \\
\hline $\mathbf{v e}$ & Lack of rainfall for direct plantation & 53.33 & \\
\hline & Over all & 65.77 & \\
\hline
\end{tabular}

With regard to technical constraints, Table 2 clearly indicates that long maturity period (95.33 MPS), non - availability of oil extraction unit in the area (81 MPS), extremely degraded conditions of soil at the plantation site (71 MPS) and non availability of improved varieties (67.66 MPS) were the major constraints faced by the beneficiaries of Barren Land Development through Jatropha Plantation. Lack of training (51 MPS) was the only constraint experienced to some extent by the beneficiaries of the service.

Under the economic constraints, all the beneficiaries of Jatropha Plantation expressed that they get less price for the produce. Similarly less price of jatropa produce in the market (97.66 MPS), lack of finance facilities (86.66 MPS) followed by lack of marketing facilities for sale of produce (66.66 MPS) were the major constraints faced by the beneficiaries of the service. Beneficiaries reported reasons as 
they were selling the produce to shopkeepers (local) as no other selling facilities are available in the area. High cost of inputs (60 MPS) was reported by the beneficiaries of Jatropha Plantation to some extent.

Perusal of Table 2 highlights that the major general constraints of Barren land Development through Jatropha plantaion experienced by the beneficaries were high mortality in the first year of plantation (76.66 MPS) and insufficient labour availability during work season (75.33 MPS) followed by lack of irrigation facilities for raising seedlings (67.66 MPS). Absence of procurement policy of the government $(55.33$ MPS) and lack of rainfall for direct plantation (53.33 MPS) were the constraints experienced to some extent by the beneficiaries of the service. It was found during discussion with the beneficiaries that plants require extra care in the first year due to its high mortality rates. Further government initiatives were less for the cultivation of jatropha. In Barren Land Development through Jatropha Plantation, 93.33 per cent beneficiaries experiencing constraints to great extent and only 6.66 per cent of the beneficiaries were experiencing constraints to some extent. The study conducted by Meena (2006) also reported alike findings that 67 per cent of total respondents faced medium level of constraints in adoption of jatropha cultivation technology. Whereas, 22.50 per cent jatropha growers were observed to be in high constraint group and only 10.50 per cent respondents perceived low level of constraints in jatropha cultivation.

In conclusion, regarding Barren land Development through Jatropha plantation service, 96.66 per cent beneficiaries had favourable opinion with MWS 2.21 and only 3.33 beneficiaries had showed favourable opinion and 93.33 per cent beneficiaries experiencing constraints to great extent also depicts in MPS 74.00.

\section{References}

A Reference Annual India. 2015. Publications Division - Ministry of Information and Broadcasting (Government of India) pp 86.

Gondalia, V.K. and Patel, G.N. 2007. An Economic Evaluation of Investment on Aonla (Emblica officinalis G.) in Gujarat. Agricultural Economics Research Review 20: 385-394

Jatana, R. and Waldia, S. 2009. Tribal Development Programmes. Mahamaya Publishing House, New Delhi. pp: 14,46,82,83,109-110 and 120-121.

Jitarwal, R. C. and Sharam, N. K. 2007. Impact of Drip Irrigation Technology among Farmers in Jaipur Region of Rajasthan. Indian Research Journal of Extension Education 7:88-89.

Meena, H. 2006. An Analytical study on status and prospects of Jatropha (Jatropha curcas L.) cultivation in Udaipur District in Rajasthan. Ph.D. thesis submitted to Maharana Pratap University of Agriculture and Technology, Udaipur, Rajasthan.

Meena, S. R., More, T. A., Singh, D. and Singh, I. S. 2009. Arid Vegetable Production Potential and Income Generation. Indian Research Journal of Extension Education. 9:72-75.

Prasad, R., Singh, A.K., Singh, L. and Singh, A. 2013. Economics of Goat Farming under Traditional low Input Production System in Uttar Pradesh. Journal of Community Mobilization and Sustainable Development 8: 09-13.

\section{How to cite this article:}

Sonali Sharma. 2019. Opinion and Constraints Analysis in Barren Land Development under Tribal Area Development Programme on Tribals of Udaipur District. Int.J.Curr.Microbiol.App.Sci. 8(04): 865-870. doi: https://doi.org/10.20546/ijcmas.2019.804.097 